International Research Journal of Engineering, IT \& Scientific Research
Available online at https://sloap.org/journals/index.php/irjeis/
Vol. 8 No. 1, January 2022, pages: 27-35
ISSN: 2454-2261
https://doi.org/10.21744/irjeis.v8n1.2046

\title{
Design of Prada Paint Dulang Craft Drying Machine to Improve Product Quality and Work Productivity of Dulang Fiber Crafters in Bangli Regency
}

A. A. Ngurah Bagus Mulawarman a

Article history:

Submitted: 09 November 2021

Revised: 27 December 2021

Accepted: 18 January 2022

\section{Keywords:}

drying machine;

fiber craft;

heat temperature;

product quality;

work productivity;

\begin{abstract}
Dulang (Balinese Language) is a tool used by Hindus as a means in ceremonies to bring holy offerings of gebogan (like holy offerings) during a ceremony. Dulang is generally made of wood which is formed in such a way and given a color to beautify its appearance. The drying process is carried out outdoors during the day at around $12.00-1.00 \mathrm{pm}$ for around 60 minutes with an ambient temperature of $30-34^{\circ} \mathrm{C}$ until the gold paint is dry. The process of drying gold paint requires a good heat temperature and drying evenly to get the results of good quality Prada paint. When the weather is cloudy or the rainy season the craftsman drying process can take place for one full day, other than that the quality of Prada (like gold color paint) is also not good that is less brilliant. Efforts to overcome this designed a gold paint drying machine. This drying machine is designed with a capacity of 4 pieces of fiber with 2 shelves.
\end{abstract}

International research journal of engineering, IT \& scientific research (C) 2022. This is an open access article under the CC BY-NC-ND license (https://creativecommons.org/licenses/by-nc-nd/4.0/).

Corresponding author:

A. A. Ngurah Bagus Mulawarman,

Department of Mechanical Engineering, Bali State Polytechnic, Indonesia.

Email address: bagusmulawarman@pnb.ac.id

a Department of Mechanical Engineering, Bali State Polytechnic, Indonesia 


\section{Introduction}

The process of making Dulang fiber craft in Bangli Regency, Bali, includes the process of printing the fiber into the shape of the Dulang fiber craft, the process of drying the mold, the process of coloring the prada paint, and the final drying process. The drying process is the separation of a small amount of water or other liquid from a material, thereby reducing the liquid content. Drying is usually the last step in a series of operations and the drying product is usually ready to pack (McCabe et al., 1993). Buckle (1995), stated that the drying speed of a material is influenced by several factors, including: (1) the physical properties of the material, (2) the geometric arrangement of the product with respect to the surface of the tool or medium for heat transfer, (3) characteristics of the drying environment (temperature, humidity, and air velocity, and (4) drying characteristics (heat transfer efficiency). A constant drying rate occurs at the beginning of the drying process which is then followed by a decreasing drying rate. This period is limited by the degree of concentration. critical water (critical moisture content) (Henderson \& Perry, 1955).

The process of drying the Prada paint is currently drying using the heat of the sun during the day for about 15 minutes until the Prada paint dries completely. In this process, enough heat is needed on all parts of the pan so that the paint quality is good and bright. The main problem faced by craftsmen is the drying process of this Prada paint when the weather is cloudy or the rainy season. If the weather is cloudy, it takes about 1 to 2 hours longer and during the rainy season, the drying process can take about 5 - 6 hours. In addition, drying in the sun requires a large area for a Dulang fiber craft. The drying process can also be done by means of the oven. The heat source is generated from the flame of firewood and the pan is placed on the flame about $50 \mathrm{~cm}$ apart and placed on an iron rack. The drying time in the oven is about 40 minutes - 50 minutes for 6 trays. The higher the temperature and the drying air velocity, the faster the drying process will take place. The higher the temperature of the drying air, the greater the heat energy carried by air so that a greater amount of mass of liquid is evaporated from the surface of the material being dried. If the drying air flow rate is higher, the faster the mass of water vapor is transferred from the material to the atmosphere. To overcome this problem, Dulang fiber Prada paint craft tray drying machine was designed with a capacity of 4 trays and 2 racks. The drying method uses a heating element so that the drying process takes place faster, the drying temperature can be adjusted and the drying heat is more evenly distributed on all layers of dried Dulang fiber prada paint craft (Zvolinschi et al., 2006; Coopersmith et al., 2014).

\section{Materials and Methods}

This research is a one-short case study with a design pre and post-test design conducted observational to the drying process. The chart can be described as follows (Corlett, 2005).

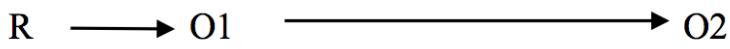

\footnotetext{
Caption:

$\mathrm{R} \quad$ : random sample

O1 : pretest

O2 : postest
}

The variables to be measured in this study include: (1). Long drying time; (2) drying quality; (3) work productivity after work by comparing the number of products produced (units) $\mathrm{x}$ the product quality score during work time (minutes)

\section{Results and Discussions}

\section{Design dryer machine}

The drying machine of Dulang prada paint is designed with an overall frame measuring $120 \mathrm{~cm} \mathrm{x} 45 \mathrm{~cm} \mathrm{x} 95 \mathrm{~cm}$ and a drying room measuring $80 \mathrm{~cm}$ x $80 \mathrm{~cm}$ x $45 \mathrm{~cm}$. In the drying room, it is stratified so that it can accommodate 4 trays, namely the top 2 pieces and the bottom 2 pieces (Hayes et al., 2018; Chao, 1998; Hallak, 2006). 


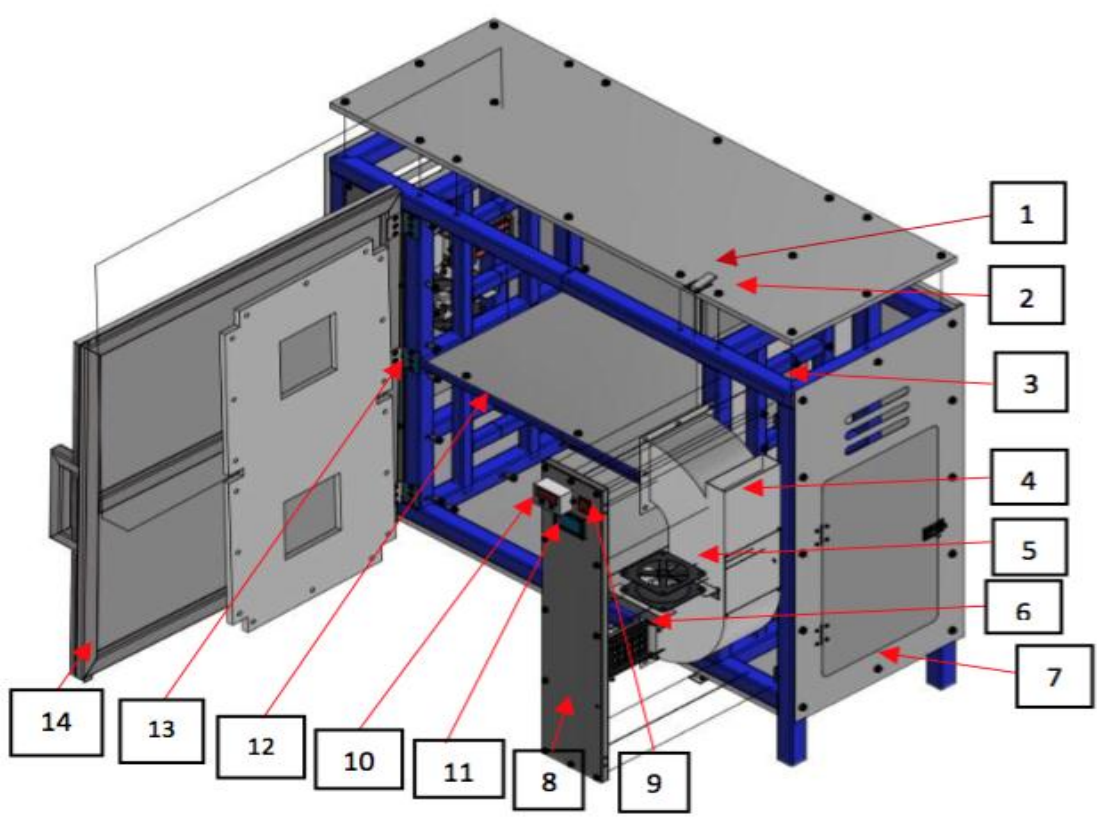

Figure 1. Frame design and drying room

$\begin{array}{lll}\text { 1. Lock } & \text { 6. Heating Element } & \text { 11. VCP Digital } \\ \text { 2. Cover Plate } & \text { 7. Fastening Bolt } & \text { 12. Rack } \\ \text { 3. Body } & \text { 8. Side Door } & \text { 13. Hinge } \\ \text { 4. Ari Ducting } & \text { 9. Switch } & \text { 14. Main Door } \\ \text { 5. Fan } & \text { 10.Temperature Control } & \end{array}$

The drying machine planning calculations include:

1) Drying room wall

The materials used for the drying walls are aluminum plate, polystyrene, and galvanized.

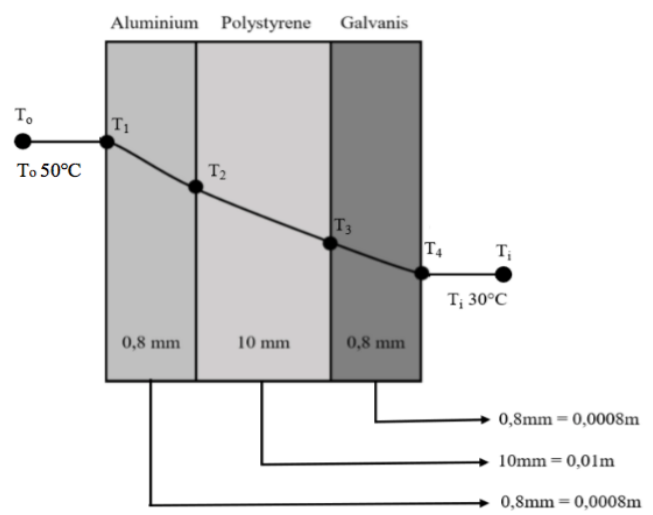

Figure 2. Heat transfer field composite structure

The results of the calculation of the heat transfer rate in the drying chamber include:

a) The area of the upper side of the drying room is $0.36 \mathrm{~m} 2$ with the heat transfer rate $(\mathrm{q})=111.11$ watts

b) The area of the lower side of the drying room is $0.36 \mathrm{~m} 2$ with the heat transfer rate $(\mathrm{q})=111.11$ watts

Mulawarman, A. A. N. B. (2022). Design of prada paint dulang craft drying machine to improve product quality and work productivity of dulang fiber crafters in Bangli regency. International Research Journal of Engineering, IT \& Scientific Research, 8(1), 27-35. https://doi.org/10.21744/irjeis.v8n1.2046 
c) The area behind the drying room is $0.64 \mathrm{~m} 2$ with a heat transfer rate $(q)=210.52$ watts

d) The area of the front of the $0.64 \mathrm{~m} 2$ drying room with heat transfer rate $(\mathrm{q})=210.52$ watts

e) The area of the left side of the drying room is $0.36 \mathrm{~m} 2$ with the heat transfer rate $(\mathrm{q})=10$ watts

f) The area of the left side of the drying room is $0.36 \mathrm{~m} 2$ with the heat transfer rate (q) $=10$ watts

g) The area on the right side of the ducting is $0.48 \mathrm{~m} 2$ with a heat transfer rate $(q)=15.38$ watts

h) The area on the left side of the ducting is $0.48 \mathrm{~m} 2$ with the heat transfer rate (q) $=15.38$ watts

So that the need for drying power in the room is 694.02 watts.

2) Drying Power Calculation

The weight of the tray dried is $3.92 \mathrm{~kg}$, assuming the temperature outside the drying room is 300 and the temperature in the drying room is 500 , the heat required is 187,520 Joules. The drying process for (t) is 20 minutes, so the power $(\mathrm{P})$ needed is 156.27 watts.

3) Drying Rate

The drying rate is measured based on the heat/heat received by Dulang in the drying room, which is 3.024 Joules. If the indoor air circulation lasts 15 minutes, the power $(\mathrm{P})$ required is 3.36 watts.

4) Requirement of Heating Element

The power required for heating elements in the room is calculated based on the heat requirements of the walls, the heat of the pan products, and the drying rate, which is 853.65 watts. For this reason, 3 heating elements with a power capacity of 300 watts were selected.

5) Machine Design Result

The drying machine of Dulang prada paint is made with hollow iron frame material, drying room with aluminum plate and galvanized plate, coated with aluminum foil. The results of the engine design are presented in Figure 3.

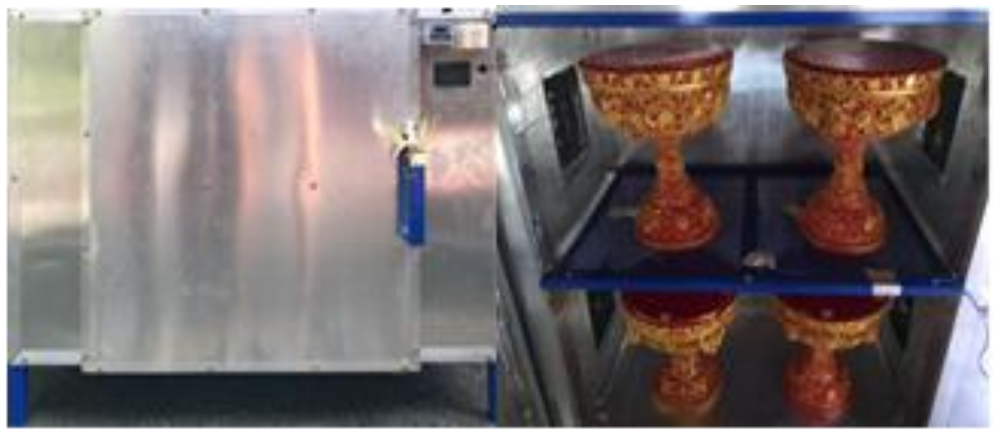

Figure 3. Drying machine of Dulang prada paint

The drying machine of Dulang prada paint testing result

1) Drying Machine Testing Without Load.

Testing when empty space aims to determine the performance of the machine without load. The test was carried out with a temperature setting of $45^{\circ} \mathrm{C}$.

Table 1

Drying room temperature and power (watts) of drying

\begin{tabular}{llllll}
\hline Times (minutes) & $\mathrm{T}_{1}\left({ }^{\circ} \mathrm{C}\right)$ & $\mathrm{T}_{2}\left({ }^{\circ} \mathrm{C}\right)$ & Voltage $(\mathrm{V})$ & Ampere $(\mathrm{A})$ & Power (watt) \\
\hline 0 & 29 & 28 & 200 & 5.74 & 783 \\
5 & 42 & 42 & 218 & 2.77 & 555 \\
10 & 45 & 44 & 220 & 0.07 & 588 \\
15 & 45 & 44 & 218 & 4.80 & 573 \\
20 & 44 & 45 & 220 & 0.17 & 521 \\
\hline
\end{tabular}


2) Drying Machine Testing with Loads

Testing the drying machine with a load of 4 prada paint trays obtained a drying time of 20 minutes, all observation points were dry (100\%).

Table 2

Testing results of drying machines with loads

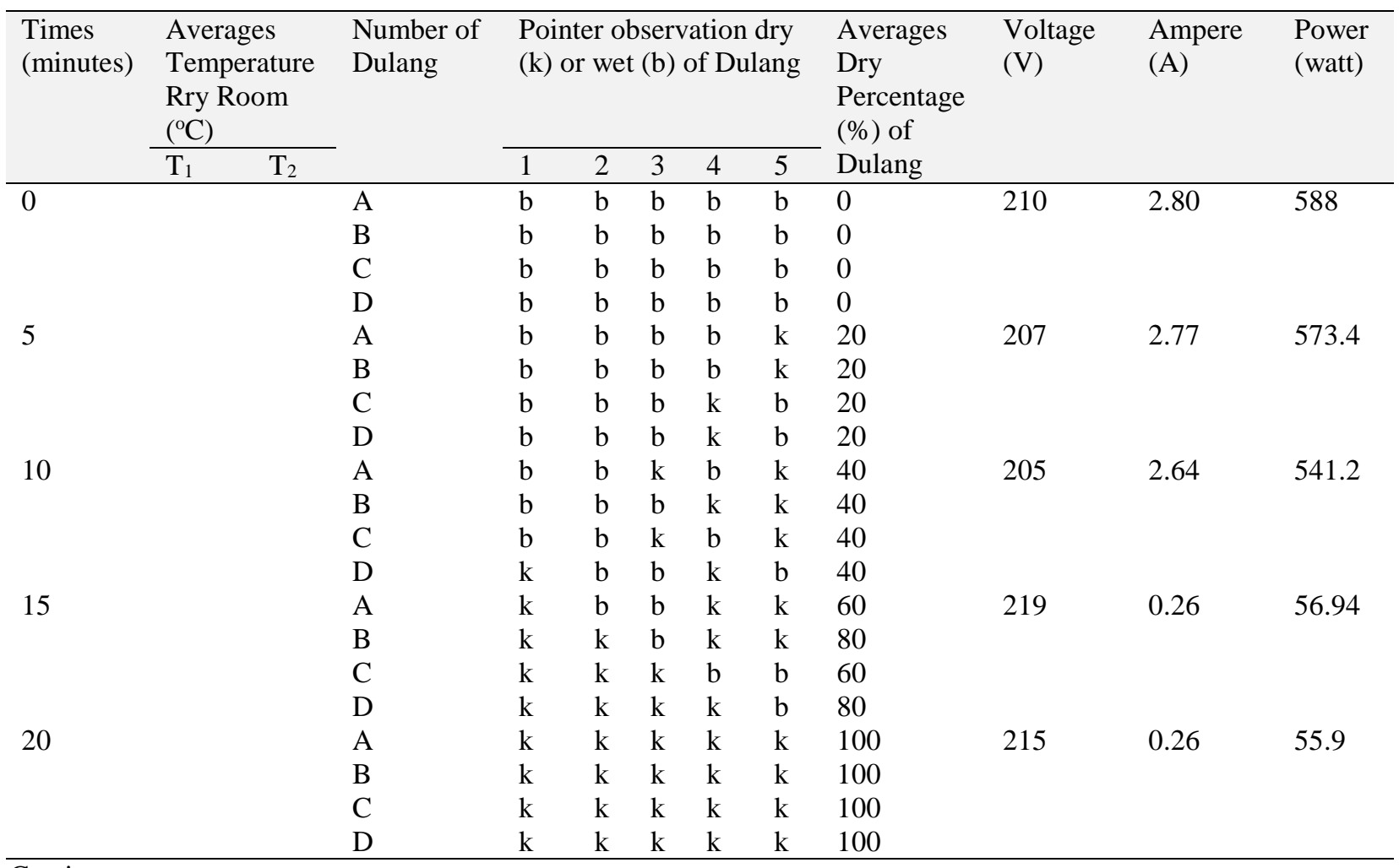

Caption:

$\mathrm{b}=$ wet; $\mathrm{k}=$ dry

Sun drying testing for dulang prada paint craft

The drying process with sunlight on 4 pieces of Prada paint tray craft obtained a long drying time of 30 minutes. All observation points were completely dry $(100 \%)$.

Table

Sun-drying testing for Dulang prada paint craft

\begin{tabular}{|c|c|c|c|c|c|c|c|c|}
\hline \multirow{2}{*}{$\begin{array}{l}\text { Times } \\
\text { (minutes) }\end{array}$} & \multirow{2}{*}{$\begin{array}{l}\text { Averages } \\
\text { Temperature } \\
\text { of Dulang } \\
\left({ }^{\circ} \mathrm{C}\right)\end{array}$} & \multirow{2}{*}{$\begin{array}{l}\text { Number of } \\
\text { Dulang }\end{array}$} & \multicolumn{5}{|c|}{ Pointer observation dry (k) or wet (b) of Dulang } & \multirow{2}{*}{$\begin{array}{l}\text { Averages Dry } \\
\text { Percentage }(\%) \\
\text { of Dulang }\end{array}$} \\
\hline & & & 1 & 2 & 3 & 4 & 5 & \\
\hline 0 & 30.0 & A & $\mathrm{b}$ & $\mathrm{b}$ & $\mathrm{b}$ & $\mathrm{b}$ & $\mathrm{b}$ & 0 \\
\hline 0 & 30.0 & B & $\mathrm{b}$ & $\mathrm{b}$ & $\mathrm{b}$ & $\mathrm{b}$ & $\mathrm{b}$ & 0 \\
\hline 0 & 30.0 & $\mathrm{C}$ & $\mathrm{b}$ & $\mathrm{b}$ & $\mathrm{b}$ & $\mathrm{b}$ & $\mathrm{b}$ & 0 \\
\hline 0 & 30.0 & $\mathrm{D}$ & $\mathrm{b}$ & $\mathrm{b}$ & $\mathrm{b}$ & $\mathrm{b}$ & $\mathrm{b}$ & 0 \\
\hline 5 & 30.5 & A & $\mathrm{b}$ & $\mathrm{b}$ & $\mathrm{b}$ & b & $\mathrm{b}$ & 0 \\
\hline 5 & 30.5 & B & $\mathrm{b}$ & $\mathrm{b}$ & $\mathrm{b}$ & $\mathrm{b}$ & $\mathrm{b}$ & 0 \\
\hline
\end{tabular}

Mulawarman, A. A. N. B. (2022). Design of prada paint dulang craft drying machine to improve product quality and work productivity of dulang fiber crafters in Bangli regency. International Research Journal of Engineering, IT \&

Scientific Research, 8(1), 27-35. https://doi.org/10.21744/irjeis.v8n1.2046 


\begin{tabular}{|c|c|c|c|c|c|c|c|c|}
\hline 5 & 30.5 & $\mathrm{C}$ & $\mathrm{b}$ & $\mathrm{b}$ & $\mathrm{b}$ & $\mathrm{b}$ & $\mathrm{b}$ & 0 \\
\hline 5 & 30.5 & D & b & b & b & b & b & 0 \\
\hline 10 & 31.0 & A & $\mathrm{b}$ & $\mathrm{k}$ & b & $\mathrm{b}$ & b & 20 \\
\hline 10 & 31.0 & B & $\mathrm{b}$ & $\mathrm{b}$ & b & $\mathrm{k}$ & $\mathrm{b}$ & 20 \\
\hline 10 & 31.0 & $\mathrm{C}$ & $\mathrm{b}$ & b & b & b & $\mathrm{k}$ & 20 \\
\hline 10 & 31.0 & D & $\mathrm{k}$ & $\mathrm{b}$ & $\mathrm{b}$ & $\mathrm{b}$ & $\mathrm{b}$ & 20 \\
\hline 15 & 31.5 & A & $\mathrm{b}$ & $\mathrm{k}$ & $\mathrm{k}$ & b & $\mathrm{k}$ & 60 \\
\hline 15 & 31.5 & B & $\mathrm{k}$ & b & b & $\mathrm{k}$ & b & 40 \\
\hline 15 & 31.5 & $\mathrm{C}$ & $\mathrm{k}$ & b & b & b & b & 20 \\
\hline 15 & 31.5 & D & b & $\mathrm{k}$ & $\mathrm{k}$ & b & b & 40 \\
\hline 20 & 31.8 & A & $\mathrm{k}$ & b & $\mathrm{k}$ & $\mathrm{k}$ & $\mathrm{k}$ & 80 \\
\hline 20 & 31.8 & B & $\mathrm{k}$ & b & $\mathrm{k}$ & $\mathrm{k}$ & b & 60 \\
\hline 20 & 31.8 & $\mathrm{C}$ & $\mathrm{k}$ & $b$ & b & $\mathrm{k}$ & $\mathrm{b}$ & 40 \\
\hline 20 & 31.8 & D & $\mathrm{k}$ & $\mathrm{k}$ & $\mathrm{k}$ & $\mathrm{b}$ & b & 60 \\
\hline 25 & 32.0 & A & $\mathrm{k}$ & $\mathrm{b}$ & $\mathrm{k}$ & $\mathrm{k}$ & $\mathrm{k}$ & 80 \\
\hline 25 & 32.0 & B & $\mathrm{k}$ & $\mathrm{k}$ & $\mathrm{k}$ & $\mathrm{k}$ & b & 80 \\
\hline 25 & 32.0 & $\mathrm{C}$ & $\mathrm{k}$ & $\mathrm{k}$ & b & $\mathrm{k}$ & b & 60 \\
\hline 25 & 32.0 & D & $\mathrm{k}$ & $\mathrm{k}$ & $\mathrm{k}$ & $\mathrm{k}$ & $\mathrm{k}$ & 100 \\
\hline 30 & 32.3 & A & $\mathrm{k}$ & $\mathrm{k}$ & $\mathrm{k}$ & $\mathrm{k}$ & $\mathrm{k}$ & 100 \\
\hline 30 & 32.3 & B & $\mathrm{k}$ & $\mathrm{k}$ & $\mathrm{k}$ & $\mathrm{k}$ & $\mathrm{k}$ & 100 \\
\hline 30 & 32.3 & $\mathrm{C}$ & $\mathrm{k}$ & $\mathrm{k}$ & $\mathrm{k}$ & $\mathrm{k}$ & $\mathrm{k}$ & 100 \\
\hline 30 & 32.3 & D & $\mathrm{k}$ & $\mathrm{k}$ & $\mathrm{k}$ & $\mathrm{k}$ & $\mathrm{k}$ & 100 \\
\hline
\end{tabular}

Caption:

$\mathrm{b}=$ wet; $\mathrm{k}=\mathrm{dry}$

\section{Product quality}

The definition of quality varies widely. According to Boetsh and Denis in Tjiptono (2000), quality is a dynamic condition related to goods and services as well as processes and environments that meet or exceed expectations. Clark (2000), also defines quality as to how consistently the product or service produced can meet the expectations and needs of internal and external customers. Meanwhile, Stevenson \& Hojati (2007) defines quality as the ability of a product or service to meet or exceed customer expectations. Quality control is an activity (company management) to maintain and direct the quality of the company's products and services as planned. According to Ahyari (1985), quality control is a preventive effort and is carried out before the product quality is damaged.

The quality of the drying results of Prada paint craft is assessed from several quality variables, including: (1). The dryness level of all parts (100\% dry), (2) texture suitability of all parts (no defective textures), (3) color suitability (no part has changed), and (4) evenly colored brightness (no the darker part). Each quality variable received is assigned a value of 1 (one), while if it is not accepted, it is given a value of 0 (zero). This assessment is carried out by the Group Leader of each craftsman as part of quality control of the product (Oğulata, 2004; Santosa \& Sutarna, 2016).

Table 4

Data mean value of product quality score $(n=12)$

\begin{tabular}{llll}
\hline No & Quality Assessment Indicators & P0 & PI \\
\hline 1 & Dryness of all part (100\% dry) & 0.7916 & 0.9166 \\
2 & Texture siuitability of all part (no texture defects) & 0.7916 & 0.8333 \\
3 & Color suitability (no discolored part) & 0.7916 & 0.9166 \\
4 & Even color brightness (no darker part) & 0.7083 & 0.9166 \\
& Mean & 0.7708 & 0.8958 \\
\hline
\end{tabular}

Information:

P0: Sun drying

PI : Machine drying 
The results of the normality test on the data mean that the product quality score at P0 and PI obtained a value ( $\mathrm{p}$ > 0.05) which means that the data is normally distributed (Doniyor \& Khabibulla, 2021; Maiti \& Giri, 2015). Thus, it can be continued with the Paired Sample t-Test to determine the significant difference in the value of the product quality score P0 with PI. The complete Paired Sample t-Test results are presented in Table 5.

Table 5

Results of paired sample t-test value of quality score in the drying process $(n=12)$

\begin{tabular}{lllll}
\hline No. & Value of Quality Score & Mean & $\mathrm{t}$ & $\mathrm{p}$ \\
\hline 1 & P0 & $0.7708 \pm 0,067$ & -4.271 & \multirow{2}{*}{0.001} \\
2 & PI & $0.8958 \pm 0,47$ & & \\
\hline
\end{tabular}

Table 5 shows the results of the different test results for the significance of the quality score of the mortar at P0 with $\mathrm{PI}$, the value of $\mathrm{t}=-4.271$, and the value of $\mathrm{p}=0.001$ is obtained, which means that the drying quality score of Dulang prada paint cans in the P0 study (sun drying) with PI research (drying with drying machine) is significantly different $(\mathrm{p}<0.05)$ so that $\mathrm{H} 0$ is rejected and $\mathrm{Ha}$ is accepted or the average quality of drying with a drying machine is better than drying with sunlight or increasing product quality 16,22 percent. Other studies that are similar to quality improvement efforts are research on redesigning drying equipment and working systems to improve the quality of seaweed by decreasing water content by $29.24 \%$ (Surata et al., 2011), and research by designing dodol stirrers ergonomically to improve the quality of dodol so that $100 \%$ meets SNI standards (Santosa, 2013).

\section{Productivity}

Work productivity is a comparison between output and input per unit of time. Work productivity can be said to increase if the number of outputs increases with the same number of inputs (Chuan et al., 2010). In general, work productivity can be formulated as follows (Manuaba, 2000).

Productivity $=\quad \frac{\text { Output }}{\text { Input } x \text { time work }}$

The input for the drying process is the amount of the Prada paint tray product. The working time is calculated from the start of taking out the canned product until the canned product is dry and taken/removed as a sign of the end of the drying process (Rezaei et al., 2019; Richardson et al., 2006). The length of working time is calculated in minutes. The output is the drying quality score. The results of productivity calculations are presented in Table 6.

Tabel 6

Wilcoxon sign ranks test productivity result $(\mathrm{n}=12)$

\begin{tabular}{lllll}
\hline No. & Productivity & Mean & z & p \\
\hline 1. & P0 & $0.00161 \pm 0,0021$ & -2.108 & 0,00 \\
2. & PI & $0.00280 \pm 0,0002$ & & 1 \\
\hline
\end{tabular}

Table 6 shows the results of the different test results for the significance of the Wilcoxon Sign Ranks Test, the value of $\mathrm{z}=-3.517$ and $\mathrm{p}=0.001$ is obtained, which means that the average work productivity of the P0 (sun drying) to PI (machine drying) study is obtained, so that $\mathrm{H} 0$ is rejected and Ha is accepted, namely the average productivity after improvement (dry with machine drying) higher than before the repair (drying sun) or increased by 73,91 percent. Ergonomic intervention research with dryer design can increase work productivity by 73,91 percent (Susana, 2018). The research Suarbawa et al. (2018), so intervention environment and work posture through ergonomic approach increase the productivity of kepeng coin workers increased work productivity $33.9 \%$ ().

Mulawarman, A. A. N. B. (2022). Design of prada paint dulang craft drying machine to improve product quality and work productivity of dulang fiber crafters in Bangli regency. International Research Journal of Engineering, IT \& Scientific Research, 8(1), 27-35. https://doi.org/10.21744/irjeis.v8n1.2046 


\section{Conclusion}

Based on the discussion, it can be concluded that the use of a drying machine in the drying process of Prada paint cans improves product quality by 16.22 percent and increase work productivity by 74.3 percent.

Conflict of interest statement

The author declared that he have no competing interest.

Statement of authorship

The author has a responsibility for the conception and design of the study. The author has approved the final article.

Acknowledgments

The authors would like to thank the department of research and community service center Bali State Polytechnic and the Ministry of Education and Culture of the Republic of Indonesia for the financing of this research. 


\section{References}

Ahyari, A. (1985). Management Produksi 2: Pengendalian Produksi (Edisi ke 3.). Yogyakarta: BPFEYOGYAKARTA.

Buckle, K. A. (1995). Fish Salting and Drying Studies at the University of New South Wales, Australia. In ACIAR proceedings (pp. 51-51). Australian Centre for International Agricultural Research.

Chao, P. (1998). Impact of country-of-origin dimensions on product quality and design quality perceptions. Journal of Business research, 42(1), 1-6. https://doi.org/10.1016/S0148-2963(97)00129-X

Chuan, T. K., Hartono, M., \& Kumar, N. (2010). Anthropometry of the Singaporean and Indonesian populations. International Journal of Industrial Ergonomics, 40(6), https://doi.org/10.1016/j.ergon.2010.05.001

Clark, B. (2000). Consumer Behaviour Online.

Coopersmith, E. J., Minsker, B. S., Wenzel, C. E., \& Gilmore, B. J. (2014). Machine learning assessments of soil drying for agricultural planning. Computers and electronics in agriculture, 104, 93-104. https://doi.org/10.1016/j.compag.2014.04.004

Corlett, E. N. (2005). Static muscle loading and the evaluation of posture. Evaluation of human work, $453-496$.

Doniyor, P., \& Khabibulla, P. (2021). Theoretical research of mechanics of yarns in assembly winding machines. International Research Journal of Engineering, IT \& Scientific Research, 7(5), 193-202. https://doi.org/10.21744/irjeis.v7n5.1928

Hallak, J. C. (2006). Product quality and the direction of trade. Journal of international Economics, 68(1), $238-265$. https://doi.org/10.1016/j.jinteco.2005.04.001

Hayes, E., Fullagar, R., Mulvaney, K., \& Connell, K. (2018). Food or fibercraft? Grinding stones and Aboriginal use of Triodia grass (spinifex). Quaternary International, 468, 271-283. https://doi.org/10.1016/j.quaint.2016.08.010

Henderson, S. M., \& Perry, R. L. (1955). Agricultural process engineering (Vol. 79, No. 4, p. 321). LWW.

Maiti, T., \& Giri, B. C. (2015). A closed loop supply chain under retail price and product quality dependent demand. Journal of Manufacturing Systems, 37, 624-637. https://doi.org/10.1016/j.jmsy.2014.09.009

Manuaba, A. (2000). Stress and Strain.

McCabe, W. L., Smith, J. C., \& Harriott, P. (1993). Unit operations of chemical engineering (Vol. 5, p. 154). New York: McGraw-hill.

Oğulata, R. T. (2004). Utilization of waste-heat recovery in textile drying. Applied energy, 79(1), 41-49. https://doi.org/10.1016/j.apenergy.2003.12.002

Rezaei, S., Behroozi-Khazaei, N., \& Darvishi, H. (2019). Microwave power adjusting during potato slice drying process using machine vision. Computers and Electronics in Agriculture, 160, 40-50. https://doi.org/10.1016/j.compag.2019.03.013

Richardson, D. J., Keavey, M. A., \& Dailami, F. (2006). Modelling of cutting induced workpiece temperatures for dry milling. International Journal of Machine Tools and Manufacture, 46(10), 1139-1145. https://doi.org/10.1016/j.ijmachtools.2005.08.008

Santosa, I. G. (2013). Perbaikan kondisi dan lingkungan kerja dengan intervensi ergonomi meningkatkan kinerja dan mutu produk pada perajin dodol di Desa Penglatan Buleleng. Disertasi, Universitas Udayana, Denpasar.

Santosa, I. G., \& Sutarna, I. N. (2016). Workload evaluation towards the dodol workers from dryer section in Buleleng Bali. International Research Journal of Engineering, IT \& Scientific Research, 2(11), 66-74. Retrieved from https://sloap.org/journals/index.php/irjeis/article/view/522

Stevenson, W. J., \& Hojati, M. (2007). Operations management. Boston: McMcGraw-Hill Irwin.

Suarbawa, I. K. G. J., Arsawan, M., Yusuf, M., \& Santiana, I. A. (2018). Improvement of environment and work posture through ergonomic approach to increase productivity of balinese kepeng coin workers in Kamasan village Klungkung Bali. In Journal of Physics: Conference Series (Vol. 953, No. 1, p. 012105). IOP Publishing.

Surata, I. W., Manuaba, A., Adiputra, N., \& Sutjana, D. P. (2011). Changing Body Posture and Working System Improves Wokers Performance and Product Quality. Indonesian Journal of Biomedical Science, 5(1), 224798.

Susana, I. G. B. (2018). Improve of worker performance and quality of anchovy with ergonomic hybrid solar dryer. ARPN Journal of Engineering and Applied Sciences, 13(5), 1662-1667.

Tjiptono, F. (2000). Manajemen jasa.

Zvolinschi, A., Johannessen, E., \& Kjelstrup, S. (2006). The second-law optimal operation of a paper drying machine. Chemical Engineering Science, 61(11), 3653-3662. https://doi.org/10.1016/j.ces.2005.12.030

Mulawarman, A. A. N. B. (2022). Design of prada paint dulang craft drying machine to improve product quality and work productivity of dulang fiber crafters in Bangli regency. International Research Journal of Engineering, IT \& Scientific Research, 8(1), 27-35. https://doi.org/10.21744/irjeis.v8n1.2046 